\title{
The Buddhist Library
}

THE BUDDHIST LIBRARY IS A NON-PROFIT SERVICE ORGANIZATION WHICH DISTRIBUTES BOOKS, CATALOGUES, MAGAZINES AND OTHER MATERIALS ON BUDDHIST TEACHINGS AND TRAINING.

THE LIBRARY RESPONDS TO ALL REQUESTS FOR INFORMATION, BUT THE MANORITY OF ITS DISTRIBUTIONS GO TO INMATES OF PENITENTIARIES IN THE UNITED STATES AND CANADA.

WE WELCOME CORRESPONDENCE FROM EVERYONE INTERESTED IN BUDDHIST THOUGHT. THE LIBRARY WILL PROVIDE INFORMATION, AND MATERIAL WHERE POSSIBLE, AND WILL ACT AS A REFERAL SERVICE TO OTHER BUDDHIST SOURCES AS APPROPRIATE.

THE BUDDHIST LIBRARY IS SUSTAINED GY DONATIONS FROM ITS SUPPORTERS AND DOES NOT CHARGE FOR ITS SERVICES.

Our life is shaped by our mind; we become what we think. Suffering follows an evil thought as the wheels of a cart follow the oxen that dram it.

Our life is shaped by aur mind; we become what we think. Joy follows a pure thought like a shadom that never leaves.

"He was angry with me, he attacked me, he defeated me, he robbed me" -- those wha dwell an such thaughts will never be free from hatred.

"He was angry with me, he attacked me, he defeated me, he robled me"-- those who da not dwell on such thanghts will surely become free fram hatred.

Tor hatred can never put an end to hatred; love alone can. This is an unalteralde lawn Peaple forget that their lives will end soon. For those who remember, quarrels come to an end.

The Dhammapada

FOR MORE INFORMATION CONTACT: BUDDHIST LIBRARY, 440 KING STREET, P.O. BOX 20101 , FREDERICKTON, NEW BRUNSWICK, E3B 6 Y8 